\title{
Anatomical Study of the Horseshoe Kidney
}

\author{
Estudio Anatómico del Riñón en Herradura \\ Octavio Tijerina de la Garza; Jaime Uresti; Edgar Urrutia de la Vega; \\ Rodrigo Enrique Elizondo-Omaña \& Santos Guzmán-López
}

TIJERINA; G. O.; URESTI, J.; URRUTIA, V. E.; ELIZONDO-OMAÑA, R. E. \& GUZMÁN-LÓPEZ, S. Anatomical study of the horseshoe kidney. Int. J. Morphol., 27(2):491-494, 2009.

SUMMARY: We present the anatomical study of a horseshoe kidney found during dissection practice at the human anatomy laboratory. The specimen consisted of a renal mass joined at its lower poles by an isthmus composed of renal parenchyma. We provide a macroscopic description of renal blood supply and the excretory system. We also discuss the anatomic and embryologic importance of this anomaly.

KEY WORDS: Horseshoe kidney; Macroscopic description; Anatomic anomaly.

\section{INTRODUCTION}

The horseshoe kidney represents one of the most frequent renal malformations with an incidence of $0.25 \%$ in the general population; being more frequent in men $(2.3: 1)$ than women (Weizer et al., 2003). It consists of the fusion of two kidneys on either side of the midline, joined by an isthmus that con be composed of renal parenchyma or fibrous tissue.

The horseshoe kidney can be located anywhere along the normal embryologic ascent of the kidney; however, it is more commonly in a low position because the isthmus does not permit ascent beyond the inferior mesenteric artery. The position of the isthmus with regard to the large vessels, the number of renal arteries, and the trajectory of the ureters can vary (Roque et al., 2007).

\section{CASE REPORT}

We report a case of horseshoe kidney that was incidentally found in a 68-year-old male during dissection practice of a human anatomy course at the School of Medicine of the Universidad Autónoma de Nuevo León, México.

Size and position of the horseshoe kidney. During a dissection of the abdominal cavity a horseshoe kidney (Fig.
1) was found with the following characteristics. It was located in front of the aorta and the vena cava at the level of L4. The isthmus connected the lower poles of both kidneys and it was located $3 \mathrm{~cm}$ below the inferior mesenteric artery. Both kidneys measured $9 \mathrm{~cm}$ on their vertical axis from upper to lower pole, while the width of the right kidney was $4.5 \mathrm{~cm}$ and of the left 4 $\mathrm{cm}$; both were $4.5 \mathrm{~cm}$ thick. The distance from the isthmus to the division of the iliac arteries was $2.5 \mathrm{~cm}$, while the distance from the diaphragmatic hiatus to the isthmus was $13.8 \mathrm{~cm}$.

Vascular system. The arterial supply of the right kidney was provided by the renal artery that originates from the lateral surface of the abdominal aorta just below the superior mesenteric artery. The right renal artery divided into anterior and posterior branches (in regard to the renal pelvis), which subdivided into upper and lower branches.

The left kidney received its arterial vascular supply from the left renal artery, which originates the inferior capsular artery. Close to the hilum it divided into anterior and posterior branches (with regard to the renal pelvis).

The isthmus received its own supply through two renal arteries that originated directly from the abdominal aorta, below the inferior mesenteric artery (Fig. 2). These arteries were very short. 
The renal veins empty into the inferior vena cava. Two right renal veins were observed (superior and inferior) and only one left renal vein with three branches: superior, inferior (anterior to the renal pelvis) and posterior.

Renal hilum, pelvis and ureter. Two small major calyxes were observed in the right kidney that converged to form a small renal pelvis that emptied into a single ureter. In the left kidney four prominent major calyxes were observed that emptied into a single ureter. Both ureters inserted independently into the posterolateral angles of the urinary bladder.

Table I. Dimensions of the kidney and isthmus that joins them in the lower pole.

\begin{tabular}{lccc}
\hline & Right kidney $(\mathbf{c m})$ & Left kidney $(\mathbf{c m})$ & isthmu \\
\hline Longitudinal axis & 9.0 & 9.0 & 4.5 \\
Cross-sectional axis & 4.5 & 4.0 & 8.0 \\
Thickness & 4.0 & 3.5 & 3.0 \\
\hline
\end{tabular}

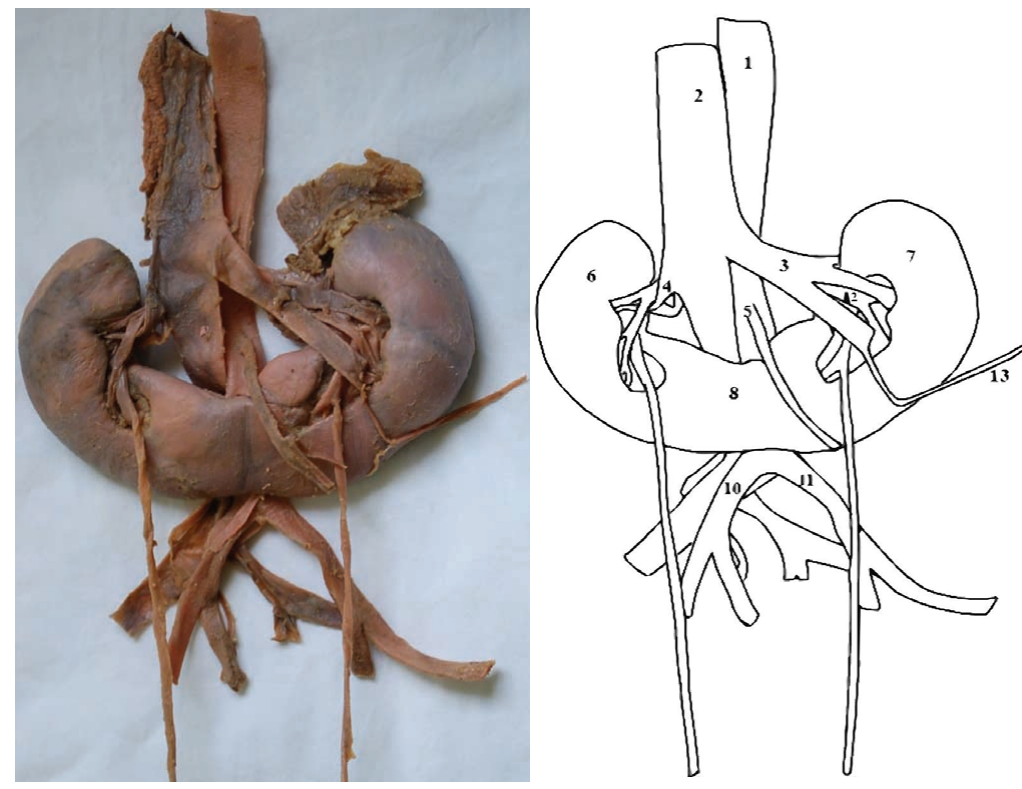

Fig. 1. Panoramic view of the anatomic sample. 1. Aorta; 2. Inferior vena cava; 3 . Left renal artery; 4. Right renal artery; 5. Inferior mesenteric artery; 6. Right kidney; 7. Left kidney; 8. Isthmus; 9. Ureters; 10. Right common iliac artery; 11. Left common iliac artery; 12. Renal arteries for the isthmus; 13. left gonadal artery (reflected).
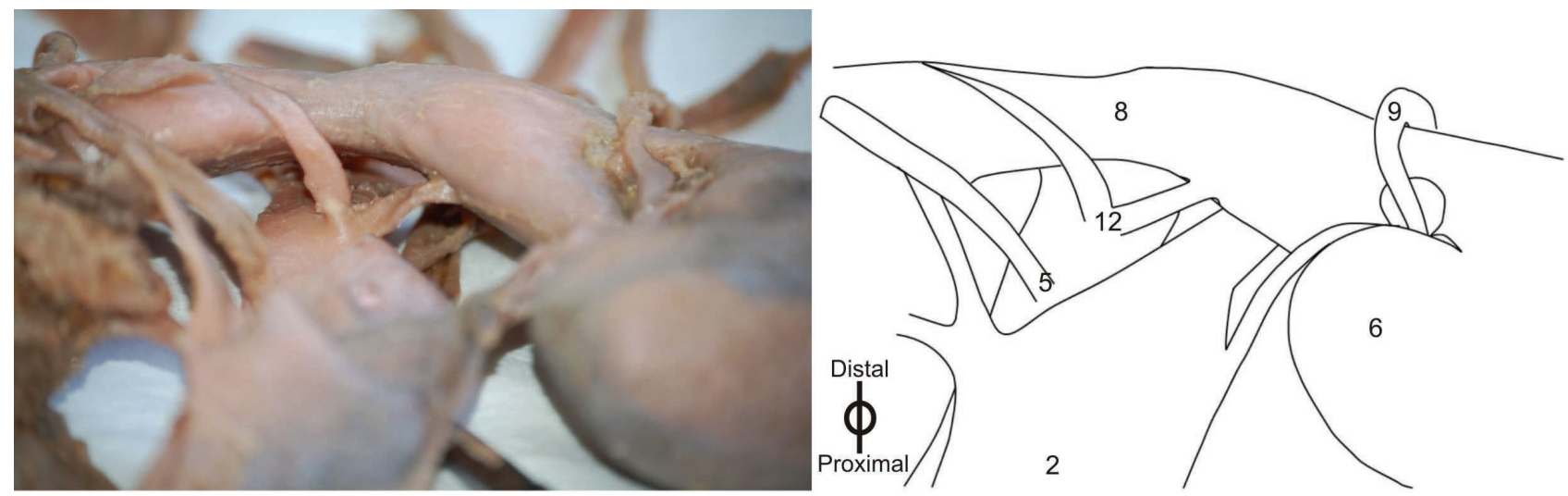

Fig. 2. View from the proximal portion where the renal arteries for the isthmus are seen. Note that the renal artery for the left isthmus (12) enters the isthmus through the anterior surface of the same. 1. Aorta; 2. Inferior vena cava; 3. Left renal artery; 4. Right renal artery; 5. Inferior mesenteric artery; 6. Right kidney, 7. Left kidney; 8. Isthmus; 9. Ureters, 10. Right common iliac artery; 11. Left common iliac artery; 12. Renal arteries for the isthmus; 13. Left gonadal artery (reflected). 


\section{DISCUSSION}

This is the first case observed in our laboratory, representing a frequency of $0.17 \%$ (1/560 cadavers) during the period 1980-2008. No other congenital malformations were observed in other organs. There are two theories about the embryogenesis of the horseshoe kidney. The classical theory of mechanical fusion proposes that during organogenesis, when the lower poles of the kidneys enter in contact and fuse in the midline, a horseshoe kidney with a fibrous isthmus is formed. More recently, it has been proposed that the horseshoe kidney is the result of a teratogenic event that involves abnormal migration of cells that form the isthmus, which is related to a parenchymal isthmus. In our report, the specimen presents a parenchymal isthmus, which is the most frequently reported in the literature.

The location of the horseshoe kidney can vary (Lai et al., 2006) along the ascending trajectory of the kidneys and is usually found, as in our report, below the origin of the inferior mesenteric artery. The measures of the kidneys considered individually had small variations, but were within expected limits.
There is a wide variation in kidney vascular supply; renal arteries can originate from the aorta, the iliac arteries, and the inferior mesenteric arteries (Bamac \& Colak, 2006; Rossi et al., 2006; Satyapal et al., 2006). In the case reported, a renal artery for each kidney was found that originated from the lateral surfaces of the abdominal aorta and two renal arteries for the isthmus that originated from the anterior surface of the abdominal aorta, distal to the inferior mesenteric artery (Yakeishi et al., 2007). In the case reported by Yoshinaga et al. (2002), two renal arteries for the isthmus were found, which originated below the inferior mesenteric artery. In the case reported by Oktem et al. (2008), only one renal artery for the isthmus was found that originated above the inferior mesenteric artery. Venous drainage, including the isthmus, occurred through three renal vessels that emptied in the vena cava independently, as reported by Yoshinaga et al. and Oktem et al.

In the report, both ureters crossed in front of the renal isthmus and drained independently in the bladder. Some cases of variations with the existence of interconnected renal pelvises and a single ureter have been reported (Yesilli et al., 2003), although they are rare.

TIJERINA; G. O.; URESTI, J.; URRUTIA, V. E.; ELIZONDO-OMAÑA, R. E. \& GUZMÁN-LÓPEZ, S. Estudio anatómico del riñón en herradura. Int. J. Morphol., 27(2):491-494, 2009.

RESUMEN: Se presenta el estudio anatómico de un riñón en herradura encontrado durante la práctica de disección en el Laboratorio de Anatomía Humana. La muestra consistió de una masa renal unida a sus polos inferiores por medio de un istmo de parénquima renal. Proporcionamos una descripción macroscópica de suministro sanguíneo renal y el sistema excretor. Asimismo, se discute la importancia anatómica y embriológica de esta anomalía.

PALABRAS CLAVE: Riñón en herradura; Descripción macroscópica; Anomalía anatómica.

\section{REFERENCES}

Bamac, B. \& Colak, T. Bilateral accessory renal arteries with retroaortic left renal vein: report of an elderly cadaver case. Clin. Anat., 19(8):714-5, 2006.

Lai, C. F.; Chiang, W. C.; Yang, J. Y.; Yan, H. C.; Lin, S. L.; Chen, Y. M.; Wu, K. D. \& Hsieh, B. S. Thoracic kidney and contralateral ureteral duplication--a case report and review of the literature. Nephrol. Dial. Transplant., 21(3):799-801, 2006.

Oktem, H.; Gozil, R.; Calguner, E.; Bahcelioglu, M.; Mutlu, S.; Kurkcuoglu, A.; Yucel, D.; Senol, E.; Babus, T. \& Kadioglu, D. Morphometric study of a horseshoe kidney. Med. Princ. Pract., 17(1):80-3, 2008.
Roque, R.; Pina, A.; Martinho, A.; Messias, H.; Nascimento, C. \& Machado, D. Horseshoe kidney transplantation. Port. J. Nephrol. Hypert., 21(4):319-24, 2007.

Rossi, U. G. ; Romano, M. \& Ferro, C. Seven renal arteries. Clin. Anat., 19(7):632-3, 2006.

Satyapal, K. S.; Haffejee, A. A.; Naidoo, M. L.; Robbs, J. V.; Akojee, S. \& Ramsaroop, L. Rare additional renal artery in live-related transplantation. Clin. Anat., 19(4):363-4, 2006.

Yakeishi, A.; Saga, T.; So, H.; Tetsuka, M.; Araki, Y.; Kobayashi, S. \& Yamaki, K. A case of horseshoe kidnay with surplus renal arteries. Kurume Med. J., 54(3-4):89-93, 2007. 
TIJERINA; G. O.; URESTI, J.; URRUTIA, V. E.; ELIZONDO-OMAÑA, R. E. \& GUZMÁN-LÓPEZ, S. Anatomical study of the horseshoe kidney. Int. J. Morphol., 27(2):491-494, 2009.

Yesilli, C.; Erdem, O.; Akduman, B.; Erdem, Z.; Gundogdu, S. \& Mungan, N. A. Horseshoe kidney with pyelic fusion and crossed single ureter. J. Urol., 170(1):175-6, 2003.

Yoshinaga, K.; Kodama, K.; Tanii, I. \& Toshimori, K. Morphological study of a horseshoe kidney with special reference to the vascular system. Anat. Sci. Int., 77(2):134-9, 2002.

Weizer, A. Z.; Silverstein, A. D.; Auge, B. K.; Delvecchio, F. C.; Raj, G.; Albala, D. M.; Leder, R. \& Preminger, G. M. Determining the incidence of horshoe kidney from radiographic data at single institution. J. Urol., 170(5):1722-6, 2003.
Correspondence to:

Rodrigo Enrique Elizondo Omaña

Human Anatomy Department

School of Medicine

Universidad Autonoma de Nuevo Leon

Monterrey

MÉXICO

Email: rod_omana@yahoo.com

Received: 28-10-2008

Accepted: 13-03-2009 